\title{
Remission of progressive multifocal leukoencephalopathy following highly active antiretroviral therapy in a man with AIDS
}

This article was published in the following Dove Press journal:

International Journal of General Medicine

12 April 2012

Number of times this article has been viewed

\author{
Katie Yoganathan' \\ David Brown ${ }^{2}$ \\ Kathir Yoganathan ${ }^{3}$ \\ 'Cardiff Medical School, Cardiff, \\ Wales, UK; ${ }^{2}$ Virus Reference \\ Department, Microbiology Services, \\ Health Protection Agency, London, \\ UK; ${ }^{3}$ Singleton Hospital, Abertawe \\ Bro Morgannwg University Health \\ Board, Swansea, UK
}

\begin{abstract}
A 43-year-old Caucasian homosexual man with AIDS presented with blurring of vision, change of personality, and memory loss in March 1999. He had first been admitted 2 months previously for treatment of Pneumocystis jiroveci pneumonia. A magnetic resonance imaging scan on admission showed multiple white matter lesions involving both subcortical cerebral hemispheres and cerebellar regions, with no mass effect or surrounding edema. JC virus was detected by nested polymerase chain reaction in the cerebrospinal fluid. These findings were diagnostic of progressive multifocal leukoencephalopathy (PML). His CD4 count was 34 cells/mL, and his HIV ribonucleic acid level was 800,789 copies $/ \mathrm{mL}$. He was treated with a combination antiretroviral therapy. He was last reviewed in October 2011. He was fully independent socially and mentally, but he still had some residual neurologic signs with right-sided homonymous hemianopia and visual agnosia. His HIV ribonucleic acid level was undetectable, and his CD4 count was 574 cells $/ \mathrm{mm}^{3}$. Although the median survival of patients with PML was poor before the antiretroviral therapy era, our patient, who is now aged 55 years, is still alive 12 years after the diagnosis. The diagnosis of PML and differential diagnosis of focal neurologic signs in HIV-positive patients are discussed in this case report.
\end{abstract}

Keywords: HIV, focal neurologic signs, cerebral toxoplasmosis, primary brain lymphoma, ischaemic stroke

\section{Case report}

A 43-year-old Caucasian man with AIDS presented with progressive confusion, blurring of vision, and personality change for 6 weeks in March 1999. He was successfully treated for Pneumocystis jiroveci pneumonia 2 months prior to his presentation. He did not have any headaches or seizures. He was afebrile. Examination revealed left cerebellar signs, dysphasia, and clear evidence of left posterior-occipital lesion with right homonymous hemianopia. He was unable to identify simple objects such as a pen or coins nor name colors correctly. He was disoriented in time and place. His CD4 count was 34 cells/ $\mathrm{mm}^{3}$. His HIV ribonucleic acid (RNA) level was 800,789 copies/mL. Serum toxoplasma immunoglobulin $\mathrm{G}$ antibodies were negative. A magnetic resonance imaging (MRI) scan on admission showed multiple white matter lesions involving both subcortical cerebral hemispheres and cerebellar regions, with no mass effect or surrounding edema (Figure 1). Cerebrospinal fluid (CSF) was clear in color with a polymorph count of three cells and a lymphocyte count of five cells. Gram staining of CSF did not show any organism, and bacterial culture of CSF was negative. CSF toxoplasma PCR was negative. CSF Mycobacterium tuberculosis culture was negative. JC virus antibodies in the blood and CSF were $1 / 81,920$ and $1 / 20,489$, respectively. ${ }^{1}$ The antibody index was 28 , indicating intrathecal production of JC virus antibodies, which was consistent
Correspondence: Kathir Yoganathan GU/HIV Medicine, Singleton Hospital, Abertawe Bro Morgannwg University Health Board, Swansea SA2 8QA, UK Email kathir.yoganathan@wales.nhs.uk submit your manuscript $\mid$ www.dovepress.com Dovepress 


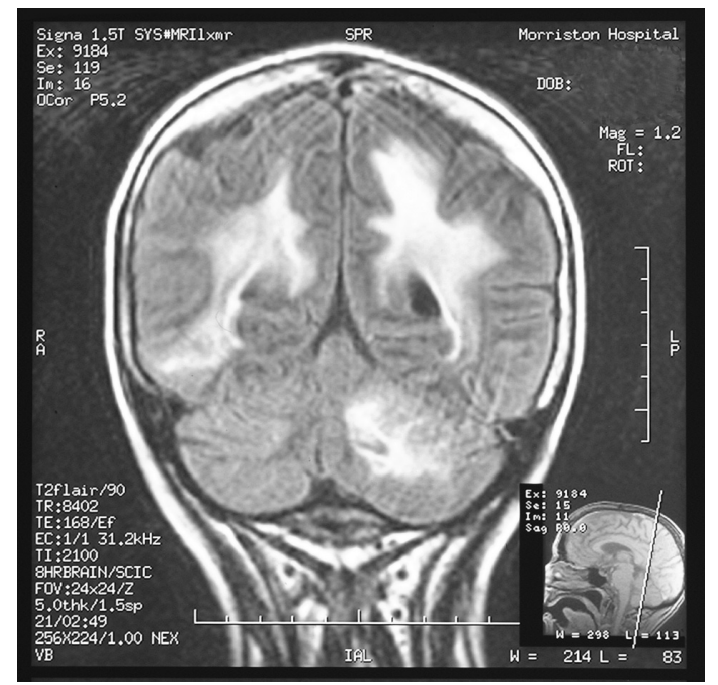

Figure I Magnetic resonance imaging scan showing multifocal white matter lesions in both subcortical cerebral hemispheres and left cerebellar regions without any mass effect or surrounding edema.

with progressive multifocal leukoencephalopathy (PML). Nested PCR for JC virus was positive in the CSF.

He was treated with nucleoside reverse transcriptase inhibitors, zidovudine (AZT), lamivudine, and the non-nucleoside reverse transcriptase inhibitor nevirapine. His cerebellar signs improved 2 months after the treatment. He was oriented in time and place. He was able to walk independently to the local shops and to pay money correctly a year after admission. He became fully independent and able to live on his own nearly 2 years after his admission, though he required frequent visits by a support worker to supervise adherence to his antiretroviral therapy (ART). His HIV RNA level became undetectable, and his CD4 count rose to 330 cells $/ \mathrm{mm}^{3}$. He developed symptoms of peripheral neuropathy 9 months after commencing ART. Zidovudine was replaced with abacavir. He was last reviewed in October 2011 when he was 55 years old. His adherence to ART was excellent without requiring any support from health care workers. He was fully independent and living on his own but still had some residual neurologic signs with homonymous hemianopia. He declined repeat lumbar puncture to look for JC virus in the CSF, as he felt that there was no reason to undergo invasive tests whilst he remained well. He is now reviewed in our HIV follow-up clinic every 6 months. His most recent HIV RNA level was undetectable, and his CD4 count was 574 cells $/ \mathrm{mm}^{3}$.

\section{Discussion}

PML is an opportunistic infection caused by a human polyomavirus, JC virus. The initial site of JC virus infection is thought to be the tonsils, and it is then carried via lymphocytes to the kidney and bone marrow, which are the sites of viral latency. Reactivation of JC virus occurs due to immunosuppression, and the virus crosses the blood-brain barrier within B lymphocytes and infects oligodendrocytes and astrocytes, causing widespread demyelinative lesions. ${ }^{2}$ PML is an AIDS-defining illness in approximately $1 \%-3 \%$ of HIV-positive patients. It occurs almost exclusively in severely immunocompromised HIV-positive patients with CD4 counts less than 100 cells $/ \mathrm{mm}^{3}$, as in our case. ${ }^{3}$ It was invariably fatal in patients with AIDS before the advent of ART, with median survival around 6 months. Our patient is still alive 12 years after the diagnosis of AIDS-related PML. Astrom et $\mathrm{al}^{4}$ first described PML in patients with chronic lymphocytic leukemia and Hodgkin's lymphoma in 1958. Although the prevalence of PML increased significantly during the HIV epidemic, it has also been widely reported in other non-HIV conditions, such as systemic lupus erythematosus and sarcoidosis, and in patients with organ transplants. ${ }^{5}$ More recently, PML has also been associated with HIV-negative patients treated with immunomodulatory drugs, especially natalizumab. ${ }^{6,7}$ The risk of developing PML is 1.47 in 1000 in patients with multiple sclerosis who are treated with natalizumab, which is similar to the risk of developing PML (one in 1000) in patients with systemic lupus erythematosus who are treated with rituximab. ${ }^{8}$ PML has also been reported in HIV-negative patients who are treated with other monoclonal antibodies such as efalizumab in patients with psoriasis. PML has also been recognized in HIV-negative patients with the use of immunosuppressive agents such as azathioprine, cyclophosphamide, methotrexate, mycophenolate, and fludaramine. Fludarabine is the most frequently implicated among immunosuppressive drugs with PML, as it is capable of depleting T lymphocytes. ${ }^{9}$

New onset of PML has been observed after initiation of ART. A rapid recovery of the immune system can trigger immune reconstitution inflammatory syndrome (PML-IRIS), which is an inflammatory reaction to clinically apparent or subclinical pathogens of JC virus. ${ }^{10}$ PML-IRIS has been reported in up to $23 \%$ of PML cases diagnosed in HIV-positive patients. ${ }^{11}$ This inflammatory reaction is often associated with contrast enhancement with edema and possible mass effect on an MRI scan. It is often acute in onset, and JC virus PCR in the CSF can be negative. ${ }^{12}$

PML patients present with a slow onset of focal neurologic features without any headaches, fever, or altered consciousness. Hemiparesis, hemianopia, aphasia, hemisensory defects, and ataxia are common features. Headaches, seizures, and neck stiffness are rare in patients with PML. ${ }^{13}$ Other common causes of focal neurologic features in HIV-positive patients 
include cerebral toxoplasmosis and primary brain lymphoma. They often present with symptoms of raised intracranial pressure such as headaches or seizures and rapidly progressive focal neurologic features. Radiologic imaging often shows multiple cerebral abscesses with surrounding edema in patients with cerebral toxoplasmosis and mass effect with cerebral edema in patients with primary brain lymphoma. Ischemic strokes in young AIDS patients causing focal neurologic signs due to acquired deficiency of protein $\mathrm{S}$ and $\mathrm{C}$ have also been reported. ${ }^{14}$

For diagnosing PML, MRI is superior to computed tomography and shows multiple white matter lesions without any mass effect or surrounding edema, and lesions are not contrast enhancing. The occipito-parietal and frontal areas are most commonly affected. Lesions in thalamus, basal ganglia, corpus callosum, and posterior fossa are rare. In our patient, lesions were found in occipito-parietal areas, causing homonymous hemianopia and visual agnosia, and in the cerebellum, causing cerebellar dysfunction. ${ }^{15} \mathrm{CSF}$ is usually normal in terms of protein, glucose, and cell counts, which help to rule out other etiology such as cryptococcal meningitis, tuberculous meningitis, or cerebral toxoplasmosis. JC virus PCR of the CSF has been shown to have specificity (92\%-99\%) and sensitivity (75\%). ${ }^{16}$ However, CSF PCR for JC virus can be negative in $25 \%$ of patients, especially in those with deep-seated lesions. Because JC virus is intermittently shed in the CSF, repeated CSF analysis may increase the sensitivity. A negative PCR, therefore, will not exclude PML. Quantifying JC virus DNA level is a useful tool to monitor the disease progression of PML. ${ }^{17}$ This was not done in our patient, as it was not available at our hospital in 1999. JC virus antibodies in the CSF, in comparison with the blood in our patient, indicate that these antibodies are produced in the CSF and are not crossed from the blood. This was confirmed by a high antibody index. ${ }^{18,19}$ Definitive diagnosis is made by brain biopsy, which characteristically shows a triad of demyelination, enlarged nuclei with inclusions of oligodendrocytes, and giant bizarre astrocytes. ${ }^{20}$

There is no effective therapy for PML. However, cytosine arabinoside, cidofovir, and meflaquine have been tried with various success. ${ }^{21-24}$ The prognosis has been improved with the use of ART, which suppresses HIV RNA level and improves immune function by raising CD4 counts. Regulatory protein Tat, which is found in HIV, is known to upregulate JC virus replication. ${ }^{25}$ The use of ART with a high central nervous system penetration effective score might be associated with prolonged survival of patients with HIV-related PML. Zidovudine and nevirapine have high CSF penetration scores. Hence, zidovudine and nevirapine are usually selected in the combination ART regimen in treating HIV-positive patients with PML. These agents halt the progression of demyelination by downregulating JC virus replication and improving survival, as in our patient.

Our patient, who was severely immunocompromised due to HIV infection, had clinical, virologic, and radiologic evidence of PML. Moreover, he did not have any other causes for his focal neurologic signs. The fact that the majority of his neurologic deficits improved with the rise of CD4 count due to the use of ART strongly suggests that his PML is in remission clinically following immune reconstitution 12 years after the diagnosis of AIDS-related PML.

In conclusion, slowly progressive focal neurologic features without any headaches or seizures, and multiple subcortical white matter lesions without any mass effect or surrounding edema with positive JC virus DNA in the CSF in an AIDS patient, are diagnostic of PML. In addition, it is not invariably fatal after the introduction of ART.

\section{Disclosure}

The authors report no conflicts of interest in this work.

\section{References}

1. Gibson PE, Knowles WA, Hand JF, Brown DWG. Detection of JC virus DNA in the cerebrospinal fluid of patients with progressive multifocal leucoencephalopathy. J Med Virol. 1993;39(4):278-281.

2. Brew BJ, Davies NWS, Cinque P, Clifford DB, Nath A. Progressive multifocal leucoencephalopathy and other forms of JC virus disease. Nat Rev Neurol. 2010;6:667-679.

3. Berger JR, Pall L, Lanska D, Whiteman M. Progressive multifocal leucoencephalopathy in patients with HIV infection. J Neurovirol. 1998;4:59-68.

4. Astrom KE, Mancall EL, Richardson EP Jr. Progressive multifocal leucoencephalopathy: a hitherto unrecognized complication of chronic lymphatic leukemia and Hodgkin's disease. Brain. 1958;81:93-111.

5. Molly ES, Calabrese LH. PML and rheumatic diseases: is there increased risk? Arthritis Rheum. 2009;60:3761-3765.

6. Brooks BR, Walker DL. Progressive multifocal leucoencephalopathy in a patient with systemic lupus erythematosus. J Rheumatol. 1999;26:1609-1612.

7. Clifford DB, DeLuca A, Simpson DM, Arendt G, Giovannono G, Nath A. Natalizumab-associated progressive multifocal leucoencephalopathy in patients with multiple sclerosis: lesions from 28 cases. Neurology. 2010;9:438-446.

8. Yousry TA, Major EO, Ryschkewitsch C, et al. Evaluation of patients treated with natalizumab for progressive multifocal leukoencephalopathy. N Engl J Med. 2006;354(9):924-933.

9. Carson KR, Focosi D, Major EO, et al. Monoclonal antibody-associated progressive multifocal leucoencephalopathy in patients treated with rituximab, natalizumab, and efalizumab: a review from the Research on Adverse Drug Events and Reports (RADAR) project. Lancet Oncol. 2009;10(8):816-824.

10. Travis J, Varma A, duPlessis D, Turnbull I, Villar FJ. Immune reconstitution associated with progressive multifocal leucoencephalopathy in human immunodeficiency virus: a case discussion and review of the literature. Neurologist. 2008;14(5):321-326. 
11. Clinque P, Koralnik IJ, Gerevini S, Miro JM, Price RW. Progressive multifocal leucoencephalopathy in HIV-1 infection. Lancet Infect Dis. 2009;9:625-636.

12. Tan K, Roda R, Ostrow L, McArthur J, Nath A. PML-IRIS in patients with HIV infection: clinical manifestations of and treatment with steroids. Neurology. 2009;72:1458-1464.

13. Khana N, Elzi L, Mueller NJ, et al. Incidence and outcome of progressive leucoencephalopathy over 20 years of the Swiss HIV Cohort Study. Clin Infect Dis. 2009;48:1459-1466.

14. Yoganathan K, Benton A. Haemorrhagic transformation of cerebral infarction in an AIDS patient - thrombophaelia screen essential! Int J STD AIDS. 2009;20:801-802.

15. Whiteman ML, Post MJ, Berger JR. Progressive multifocal leucoencephalopathy in $47 \mathrm{HIV-seropositive} \mathrm{patients:} \mathrm{neuroimaging} \mathrm{with} \mathrm{clinical}$ and pathologic correlation. Radiology. 1993;187:233-240.

16. Cinque $\mathrm{P}$, Vago $\mathrm{L}$, Dahl $\mathrm{H}$, et al. Polymerase chain reaction on cerebrospinal fluid for diagnosis of virus-associated opportunistic diseases of the central nervous system in HIV-infected patients. AIDS. 1996;10(9):951-958.

17. Garcia De Viedma D, Diaz Infantes M, Miralles P, et al. JC virus load in progressive multifocal leukoencephalopathy: analysis of the correlation between the viral burden in cerebrospinal fluid, patient survival and the volume of neurological lesions. Clin Infect Dis. 2002;34:1568-1575.

18. Guillaume B, Sindic CJ, Weber T. Progressive multifocal leucoencephalopathy: JCV antibodies in the cerebrospinal fluid. Eur J Neurol. 2000;7:101-106.
19. Brooks BR, Walker DL. Progressive multi-focal leucoencephalopathy. Neurol Clin. 1984;2:299-313.

20. Knowles WA, Luxton RW, Hand JF, Garder SD, Brown DWG. The JC virus antibody response in serum and cerebrospinal fluid in progressive multifocal leucoencephalopathy. Clin Diagn Virol. 1995;4(2):183-194.

21. Huang SS, Skolasky RL, Dal Pan GJ, Royal W III, McArthur JC. Survival prolongation in HIV-associated progressive multifocal leucoencephalopathy treated with alpha-interferon: an observational study. J Neurovirol. 1998;4:324-332.

22. Hall CD, Dafni U, Simpson D, et al. Failure of cytarabine in progressive multifocal leukoencephalopathy associated with human immunodeficiency virus infection. AIDS Clinical Trials Group 243 Team. N Engl J Med. 1998;338(19):1345-1351.

23. De Luca A, Ammassari A, Pezzotti P, et al. 9/99, IRINA, ACTG 363 Study Groups. Cidofovir in addition to antiretroviral treatment is not effective for AIDS-associated progressive multifocal leukoencephalopathy: a multicohort analysis. AIDS. 2008;22(14):1759-1767.

24. Brickelmaier M, Lugovskoy A, Kartikeyan R, et al. Identification and characterization of mefloquine efficacy against JC virus in vitro. Antimicrob Agents Chemother. 2009;53(5):1840-1849.

25. Gasnault J, Lanoy E, Bentata M, Gulgust M, Costagliola D. Intracerebral penetrating ART are more efficient on survival of HIV + patients with progressive multifocal leucoencephalopathy (ANRS CO4-FHDH). Poster presented at the 16th Conference on Retroviruses and Opportunistic Infections; February 8-11, 2009, Montreal, QC, Canada.
International Journal of General Medicine

\section{Publish your work in this journal}

The International Journal of General Medicine is an international, peer-reviewed open-access journal that focuses on general and internal medicine, pathogenesis, epidemiology, diagnosis, monitoring and treatment protocols. The journal is characterized by the rapid reporting of reviews, original research and clinical studies across all disease areas.

\section{Dovepress}

A key focus is the elucidation of disease processes and management protocols resulting in improved outcomes for the patient. The manuscript management system is completely online and includes a very quick and fair peer-review system. Visit http://www.dovepress.com/ testimonials.php to read real quotes from published authors. 